\title{
Improving Early Childhood Teacher's Dance Ability in Traditional Dance through Sport Approach and Tutorial Video
}

\author{
Diah Andika Sari \\ Early Childhood Teacher Education Programme \\ Faculty of Education Science, Muhammadiyah University of Jakarta \\ Jakarta, Indonesia \\ diah_mursil@yahoo.com
}

\begin{abstract}
The role of teacher in introducing and teaching traditional dance to early childhood is enormous. This study aimed to improve the early childhood teacher's dance ability in traditional dance through sport approach and tutorial video. This research used Classroom Action Research method. From the results, there was the improvement of early childhood teacher's dance ability in traditional dance from pre cycle with $50 \%$ to $64 \%$ in cycle $1,76 \%$ in cycle 2 , and $81 \%$ in Dance performance. So it can be concluded that the exercise method with sports approach and tutorial video can increase the early childhood teacher's dance ability in traditional dance, which was also as student of Early Childhood Education Programme, in Faculty of Education Science, Muhammadiyah University of Jakarta.
\end{abstract}

Keywords--early childhood teacher's; dance ability; traditional dances; exercise method; sport approach; tutorial video

\section{INTRODUCTION}

The development of time, age, and also technology have caused art and cultural traditions began to be forgotten or abandoned by the society. When some art begins to be questioned by its cognate identity, we just question it.

Why this can be happened. Do we already love, care for, and preserve our cultural arts? Does our next generation know its cultural art? If the younger generation does not know the art of their culture, how can they feel the loss of a cultural heritage they do not recognize?

The role of teachers to introduce and teach traditional dance to the early childhood is enormous. From the result of observation, interview and questionnaire given to 43 students of Early Childhood Education Program, FIP UMJ, all of whom have become early childhood teachers, obtained data that $62 \%$ of teachers have never danced again since the last 5 to 10 years (since elementary school). The rest had never danced, felt unable to dance, did not like to dance, and, much less to teach

This study aims to determine whether the exercise method with sports approach and tutorial DVD can improve the ability of traditional dance of Early Childhood Education Program teachers, students of Early Childhood Education Program, FIP UMJ, Jakarta [1].

\section{THEORETICAL FRAMEWORK}

A. Early Childhood Teachers' Dance Ability of Traditional Dance

According to Corrie Hartong [2]. "Dance is the regularity of a rhythmic form of body motion in a space". While Louis Ellfedt, reveals his concept that, "the art of dance is an expression, a statement, an expression in motion and contains comments on the reality that persists in the minds of the audience after the show is over. While the elements of a dance are time, space, and energy [3].

Dancing is a complex motoric activity and can develop many aspects of child development [4]. Therefore, one of the competence of early childhood teachers is to dance in addition to also be able to tell and let simple musical instruments. Dance as Media Introduction of Body Mechanization Function, 2) As Body Formation Media, 3) Dance as Media of Self Socialization, 4) As Media of Introduction of Science, 4) Growing Personality, 5) Media human Introduction Characteristics, 6) As Media Communication, both non-verbal communication and aesthetic communication 7) As Media Understanding Cultural Values [5].

Traditional dance is a dance that prevails in a certain ethnic environment that is hereditary, so that traditional dances have certain rules and standards [6].

\section{B. Exercise method with Sport Approach}

Dance and movement has a relationship that can not be separated. In dancing, people have to learn, and know about the movement, until it finally produces movement. Therefore dancing requires practice. Understanding the training that comes from the training is the application of a plan to improve the ability of exercise that contains material theory and practice, methods, and rules of implementation in accordance with the goals and objectives to be achieved (Marin in Nossek, 1982). Meanwhile, according to Harre in Nossek (1982) training derived from the word training is a process of improving the ability to exercise with a scientific approach, using the principles of planned and regular education, so as to 
improve one's readiness and ability [7]. (Sukadiyanto: 2011, p.5).

Dancing as a motoric activity is also similar with a sport activity. Dancing practice should also be made the appropriate principles like sport activities. Where the main task in the exercise is to explore, develop the concept of practice by combining practical experience and scientific approach, so that the practice of training can be precise, fast, effective and efficient. For that the process of training is always characterized, among others: (1) Aims to achieve a better level of ability, require a certain time (phasing), and require precise and careful planning. (2) Must be regular / consistent, continuous and progressive. (3) At one time face-to-face (one session / one unit of training) must have a purpose and a goal. (4) The exercise material shall contain theoretical and practical material, so that the comprehension and mastery of the skills become permanently permanent. (5) Using certain methods, which are the most effective ways that are planned gradually taking into account the difficulty factor, the complexity of motion, and the emphasis on the training objectives. (6) In one practice or one meeting always consist of: Introduction / Direction, Warming up, Main Exercise, Supplementary Exercise for Muscle Fitness and Fitness Energy, Cooling Down and Cover [8].

According to Fitts and Postner, exercise is a physical exercise activity program designed to improve some skills and increase one's energy capacity in special activities [9].

Physical Ability of a person is basically seen from several aspects, among others are (Wiseman \& Bouncher: 2011): 1) Endurance, is duration or duration of a person able to perform physical activity, 2) Strength, 3) Flexibility, which is the breadth of one's joint motion in physical activity, 4) Agility, is the ability to move quickly in all directions [10].

Dancing as activity of motion and learning of motion need to do planning of dance practice which fulfill the principles of exercise (Sukadiyanto, 2011, 14-15), namely: (1) Readiness Principle, material and dose of exercise must be adjusted to the age of the participants. (2) Individual principles of differing ability to respond to exercise, including heredity, maturity, nutrition, rest and sleep, fitness, environment, injury, and motivation. (3) Warming-Up and Cooling-Down. Principles The use of warming according to Stone and Kroll (1991) helps increase body temperature, improves blood circulation, heart rate, breathing, oxygen intake, and prepares bones, joints, muscles, tendons and ligaments. Cooling down is as important as warming-up activity [11].

\section{DVD Tutorial}

Audio-visual media is a set of tools that can project moving and voiced images, including Video-DVD [12].

\section{RESEARCH METHOD}

This research was conducted on students who are also Early Childhood teachers, on the campus of Faculty of Education Science, Muhammadiyah University Jakarta, Cirendeu, Ciputat, South Jakarta, with 43 students. In the academic year 2102/2013, March -July 2013. This research used action research research method. One of the benefits of this research is to find a strategy in solving problems. Researcher follows the research procedures disclosed by Kemmis and McTaggar stated four components namely; planning, action, observe and reflection.

Table 1. Instruments of Early Childhood Teachers' Dance Ability of

\begin{tabular}{|c|l|}
\hline No & \multicolumn{1}{|c|}{ The ability to dance } \\
\hline 1 & The ability to move to music \\
\hline 2 & Gestures Balancing \\
\hline 3 & Coordinating of body movements (eye-hand and foot) \\
\hline 4 & Kem The ability to perform the right dance moves \\
\hline 5 & $\begin{array}{l}\text { Ability to follow the dance movements are taught } \\
\text { completely. }\end{array}$ \\
\hline 6 & Flexibility / Gesture of body / flexibility \& Beauty \\
\hline 7 & Ability to express during dancing \\
\hline
\end{tabular}

Table 2. Exercise Method with Sport Approach and Tutorial DVD

\begin{tabular}{|c|c|c|c|c|}
\hline Action & Cycle 1 & \multirow{3}{*}{$\begin{array}{c}\text { Dura } \\
\text { tion }\end{array}$} & Cycle 2 & \multirow{3}{*}{$\begin{array}{c}\text { Dura } \\
\text { tion }\end{array}$} \\
\hline Dance & Incription & & Dance option & \\
\hline Media & Direct Tutorial & & Tutorial DVD & \\
\hline \multirow{3}{*}{$\begin{array}{l}\text { Treat } \\
\text { ment } 1\end{array}$} & \multirow{3}{*}{$\begin{array}{l}\text { Opening: DVD } \\
\text { Learning - Aku } \\
\text { cinta Indonesia } k u \text {, } \\
\text { getting to know } \\
\text { Indonesian, } \\
\text { traditional dances } \\
\text { from every } \\
\text { province } \\
\text { Know the different } \\
\text { movements of } \\
\text { traditional } \\
\text { Indonesian dance }\end{array}$} & \multirow{3}{*}{$\begin{array}{l}150 \\
\operatorname{mins}\end{array}$} & $\begin{array}{l}\text { Dancing } \\
\text { Groups } \\
\text { Selection ( } 8 \\
\text { groups, @ 5-6 } \\
\text { students/group) }\end{array}$ & $\begin{array}{c}50 \\
\operatorname{mins}\end{array}$ \\
\hline & & & $\begin{array}{l}\text { Warming up } \\
\text { for endurance } \\
\text { and agility } \\
\text { Main Exercise: } \\
\text { Dance Review } \\
\text { - Step 1 }\end{array}$ & $\begin{array}{l}40 \\
50\end{array}$ \\
\hline & & & $\begin{array}{l}\text { Closing/coolin } \\
\text { g down }\end{array}$ & $\begin{array}{c}10 \\
\text { mins }\end{array}$ \\
\hline \multirow{3}{*}{$\begin{array}{l}\text { Treat } \\
\text { ment } \\
2\end{array}$} & $\begin{array}{lr}\text { Opening: } & \text { DVD } \\
\text { Learning - Selamat } \\
\text { Datang di } & \text { Sumatra } \\
\text { Barat, get to know } \\
\text { Westr Sumatra } \\
\text { closer }\end{array}$ & $\begin{array}{l}90 \\
\mathrm{mi} \\
\mathrm{ns}\end{array}$ & $\begin{array}{l}\text { Opening and } \\
\text { Sport warming } \\
\text { up with } \\
\text { flexibility and } \\
\text { strength }\end{array}$ & $\begin{array}{l}50 \\
\operatorname{mins}\end{array}$ \\
\hline & \multirow[t]{2}{*}{$\begin{array}{l}\text { Introduction Sports } \\
\text { for endurance and } \\
\text { agility }\end{array}$} & \multirow[t]{2}{*}{$\begin{array}{l}60 \\
\operatorname{mins}\end{array}$} & $\begin{array}{l}\text { Repetation : } \\
\text { Step 1 } \\
\text { Main Exercise: } \\
\text { Dance Surgery } \\
\text { - Step 2 } \\
\end{array}$ & $\begin{array}{l}20- \\
70 \\
\text { mins }\end{array}$ \\
\hline & & & $\begin{array}{l}\text { Closing } \\
\text { cooling down }\end{array}$ & $\begin{array}{c}10 \\
\text { mins }\end{array}$ \\
\hline \multirow{4}{*}{$\begin{array}{l}\text { Treat } \\
\text { ment } 3\end{array}$} & $\begin{array}{l}\text { Opening: } \\
\text { Learning: } \\
\text { recognize } \\
\text { various thaditional } \\
\begin{array}{l}\text { dances of West } \\
\text { Sumatra }\end{array} \\
\end{array}$ & $\begin{array}{l}40 \\
\mathrm{mi} \\
\mathrm{ns}\end{array}$ & \multirow{2}{*}{$\begin{array}{l}\text { Opening and } \\
\text { Warming up } \\
\text { for endurance } \\
\text { and agility }\end{array}$} & \multirow[t]{2}{*}{$\begin{array}{r}50 \\
\operatorname{mins}\end{array}$} \\
\hline & $\begin{array}{l}\text { The introduction of } \\
\text { exercise to } \\
\text { flexibility and } \\
\text { strength }\end{array}$ & $\begin{array}{l}50 \\
\mathrm{mi} \\
\mathrm{ns}\end{array}$ & & \\
\hline & $\begin{array}{l}\text { Main Exercise : } \\
\text { Tutorial Step } 1\end{array}$ & $\begin{array}{l}50 \\
\operatorname{mins}\end{array}$ & $\begin{array}{l}\text { Repetition : Step } \\
\text { 1- 3Main } \\
\text { Exercise: } \\
\text { Review - Step } 3\end{array}$ & $\begin{array}{l}90 \\
\operatorname{mins}\end{array}$ \\
\hline & $\begin{array}{l}\text { Closing/cooling } \\
\text { down }\end{array}$ & $\begin{array}{l}10 \\
\text { mins }\end{array}$ & $\begin{array}{l}\text { Closing/ } \\
\text { Cooling down }\end{array}$ & $\begin{array}{c}10 \\
\text { mins }\end{array}$ \\
\hline
\end{tabular}


Table 2. Exercise

\begin{tabular}{|c|c|c|c|c|}
\hline \multirow{3}{*}{$\begin{array}{l}\text { Treat } \\
\text { ment } 4\end{array}$} & $\begin{array}{l}\text { Opening and Sports } \\
\text { Warming up for } \\
\text { endurance and agility }\end{array}$ & $\begin{array}{l}50 \\
\mathrm{mi} \\
\mathrm{ns}\end{array}$ & $\begin{array}{l}\text { Opening and } \\
\text { Sport Warming } \\
\text { up flexibility } \\
\text { and strength }\end{array}$ & $\begin{array}{r}50 \\
\text { Mins }\end{array}$ \\
\hline & $\begin{array}{l}\text { Main Exercise: } \\
\text { Repeating Step 1 } \\
\text { and Tutorial Step } 2\end{array}$ & $\begin{array}{l}90 \\
\mathrm{mi} \\
\mathrm{ns}\end{array}$ & $\begin{array}{l}\text { Repetition - } \\
\text { Step 4 } \\
\text { Main Exercise: } \\
\text { Step 1-2-3 }\end{array}$ & $\begin{array}{l}90 \\
\text { mins }\end{array}$ \\
\hline & $\begin{array}{l}\text { Closing/cooling } \\
\text { down }\end{array}$ & 10 & $\begin{array}{l}\text { Closing/cooling } \\
\text { session }\end{array}$ & $\begin{array}{c}10 \\
\text { mins }\end{array}$ \\
\hline \multirow{3}{*}{$\begin{array}{l}\text { Treat } \\
\text { ment } 5\end{array}$} & $\begin{array}{l}\text { Opening and Sport } \\
\text { Warming up } \\
\text { flexibility } \\
\text { strength }\end{array}$ & $\begin{array}{l}50 \\
\mathrm{mi} \\
\mathrm{ns}\end{array}$ & $\begin{array}{l}\text { Opening and } \\
\text { Sports } \\
\text { Warming up } \\
\text { for endurance } \\
\text { and agility }\end{array}$ & $\begin{array}{c}50 \\
\text { mins }\end{array}$ \\
\hline & $\begin{array}{l}\text { Main Exercise: } \\
\text { Repeating Step } 1 \\
\text { and Tutorial Step } 3\end{array}$ & $\begin{array}{l}90 \\
\mathrm{mi} \\
\mathrm{ns}\end{array}$ & $\begin{array}{l}\text { Repetition : Step } \\
1-2-3 \\
\text { Main Exercise : } \\
\text { Review - Step } 4\end{array}$ & $\begin{array}{l}90 \\
\text { mins }\end{array}$ \\
\hline & $\begin{array}{l}\text { Closing/cooling } \\
\text { down }\end{array}$ & $\begin{array}{l}10 \\
\text { mins }\end{array}$ & $\begin{array}{l}\text { Closing/cooling } \\
\text { down }\end{array}$ & $\begin{array}{c}10 \\
\text { mins }\end{array}$ \\
\hline \multirow{3}{*}{$\begin{array}{l}\text { Treat } \\
\text { ment } 6\end{array}$} & $\begin{array}{l}\text { Opening and } \\
\text { Sports Warming up } \\
\text { for endurance and } \\
\text { agility }\end{array}$ & $\begin{array}{l}50 \\
\mathrm{mi} \\
\mathrm{ns}\end{array}$ & $\begin{array}{l}\text { Opening and } \\
\text { Sport Warming } \\
\text { up flexibility } \\
\text { and strength }\end{array}$ & $\begin{array}{l}50 \\
\text { mins }\end{array}$ \\
\hline & $\begin{array}{l}\text { Main Exercise: } \\
\text { Repeating Step 1- } \\
2-3 \text { and Tutorial } \\
\text { Step } 4\end{array}$ & $\begin{array}{l}90 \\
\mathrm{mi} \\
\mathrm{ns}\end{array}$ & $\begin{array}{l}\text { Repetition : Step } \\
1-2-3-4\end{array}$ & $\begin{array}{l}90 \\
\operatorname{mins}\end{array}$ \\
\hline & $\begin{array}{l}\text { Closing/cooling } \\
\text { down }\end{array}$ & $\begin{array}{l}10 \\
\mathrm{mi} \\
\mathrm{ns}\end{array}$ & $\begin{array}{l}\text { Closing/cooling } \\
\text { down }\end{array}$ & $\begin{array}{l}10 \\
\text { mins }\end{array}$ \\
\hline \multirow{4}{*}{$\begin{array}{l}\text { Treat } \\
\text { ment } 7\end{array}$} & $\begin{array}{l}\text { Opening and Sport } \\
\text { Warming up } \\
\text { flexibility } \\
\text { strength }\end{array}$ & $\begin{array}{l}50 \\
\mathrm{mi} \\
\mathrm{ns}\end{array}$ & $\begin{array}{l}\text { Opening and } \\
\text { Sports Wraming } \\
\text { up for endurance } \\
\text { and agility } \\
\end{array}$ & $\begin{array}{c}50 \\
\min \\
\mathrm{s}\end{array}$ \\
\hline & $\begin{array}{l}\text { Main Exercise: } \\
\text { Repeating Step 1- } \\
2-3-4\end{array}$ & $\begin{array}{l}90 \\
\mathrm{mi} \\
\mathrm{ns}\end{array}$ & $\begin{array}{l}\text { Repetition: Step } \\
1-2-3-4 \\
\text { Composition }\end{array}$ & $\begin{array}{c}90 \\
\text { mins }\end{array}$ \\
\hline & $\begin{array}{l}\text { Closing/cooling } \\
\text { down }\end{array}$ & $\begin{array}{l}10 \\
\min \\
\mathrm{s}\end{array}$ & $\begin{array}{l}\text { Closing/cooling } \\
\text { down }\end{array}$ & $\begin{array}{l}10 \\
\text { mins }\end{array}$ \\
\hline & Post test 1 & & Post test 2 & \\
\hline $\begin{array}{l}\text { FINAL } \\
\text { TEST }\end{array}$ & \multicolumn{4}{|c|}{ PERFORMANCE } \\
\hline
\end{tabular}

\section{RESULT AND DISCUSSION}

Table 3. Result

\begin{tabular}{|c|c|c|c|c|}
\hline No & $\begin{array}{c}\text { PRE } \\
\text { CYCLE }\end{array}$ & $\begin{array}{c}\text { CYCLE } \\
1\end{array}$ & $\begin{array}{c}\text { CYCLE } \\
2\end{array}$ & $\begin{array}{l}\text { PERFOR } \\
\text { MANCE }\end{array}$ \\
\hline 1 & $46 \%$ & $57 \%$ & $61 \%$ & $64 \%$ \\
\hline 2 & $50 \%$ & $61 \%$ & $61 \%$ & $68 \%$ \\
\hline 3 & $54 \%$ & $79 \%$ & $93 \%$ & $96 \%$ \\
\hline 4 & $50 \%$ & $64 \%$ & $64 \%$ & $75 \%$ \\
\hline 5 & $46 \%$ & $57 \%$ & $64 \%$ & $71 \%$ \\
\hline 6 & $50 \%$ & $61 \%$ & $64 \%$ & $75 \%$ \\
\hline 7 & $50 \%$ & $61 \%$ & $82 \%$ & $86 \%$ \\
\hline 8 & $50 \%$ & $61 \%$ & $82 \%$ & $86 \%$ \\
\hline 9 & $50 \%$ & $64 \%$ & $82 \%$ & $86 \%$ \\
\hline 10 & $50 \%$ & $64 \%$ & $86 \%$ & $86 \%$ \\
\hline 11 & $50 \%$ & $64 \%$ & $86 \%$ & $86 \%$ \\
\hline 12 & $50 \%$ & $64 \%$ & $86 \%$ & $86 \%$ \\
\hline 13 & $50 \%$ & $61 \%$ & $68 \%$ & $79 \%$ \\
\hline 14 & $50 \%$ & $61 \%$ & $68 \%$ & $75 \%$ \\
\hline 15 & $46 \%$ & $57 \%$ & $64 \%$ & $79 \%$ \\
\hline
\end{tabular}

Table 3. Cont

\begin{tabular}{|c|c|c|c|c|}
\hline 16 & $50 \%$ & $61 \%$ & $68 \%$ & $82 \%$ \\
\hline 17 & $50 \%$ & $61 \%$ & $68 \%$ & $75 \%$ \\
\hline 18 & $54 \%$ & $75 \%$ & $96 \%$ & $96 \%$ \\
\hline 19 & $50 \%$ & $68 \%$ & $61 \%$ & $79 \%$ \\
\hline 20 & $50 \%$ & $68 \%$ & $86 \%$ & $86 \%$ \\
\hline 21 & $50 \%$ & $68 \%$ & $86 \%$ & $86 \%$ \\
\hline 22 & $50 \%$ & $68 \%$ & $86 \%$ & $86 \%$ \\
\hline 23 & $50 \%$ & $68 \%$ & $86 \%$ & $86 \%$ \\
\hline 24 & $50 \%$ & $68 \%$ & $86 \%$ & $86 \%$ \\
\hline 25 & $50 \%$ & $68 \%$ & $86 \%$ & $86 \%$ \\
\hline 26 & $50 \%$ & $61 \%$ & $64 \%$ & $71 \%$ \\
\hline 27 & $50 \%$ & $61 \%$ & $64 \%$ & $71 \%$ \\
\hline 28 & $46 \%$ & $57 \%$ & $64 \%$ & $68 \%$ \\
\hline 29 & $50 \%$ & $61 \%$ & $68 \%$ & $75 \%$ \\
\hline 30 & $50 \%$ & $61 \%$ & $64 \%$ & $68 \%$ \\
\hline 31 & $54 \%$ & $64 \%$ & $96 \%$ & $96 \%$ \\
\hline 32 & $50 \%$ & $68 \%$ & $71 \%$ & $75 \%$ \\
\hline 33 & $50 \%$ & $68 \%$ & $64 \%$ & $68 \%$ \\
\hline 34 & $50 \%$ & $68 \%$ & $86 \%$ & $86 \%$ \\
\hline 35 & $50 \%$ & $68 \%$ & $86 \%$ & $86 \%$ \\
\hline 36 & $50 \%$ & $68 \%$ & $86 \%$ & $86 \%$ \\
\hline 37 & $50 \%$ & $68 \%$ & $86 \%$ & $86 \%$ \\
\hline 38 & $50 \%$ & $68 \%$ & $86 \%$ & $86 \%$ \\
\hline 39 & $50 \%$ & $68 \%$ & $86 \%$ & $86 \%$ \\
\hline 40 & $50 \%$ & $61 \%$ & $86 \%$ & $89 \%$ \\
\hline 41 & $50 \%$ & $61 \%$ & $68 \%$ & $79 \%$ \\
\hline 42 & $50 \%$ & $61 \%$ & $68 \%$ & $79 \%$ \\
\hline 43 & $46 \%$ & $57 \%$ & $61 \%$ & $68 \%$ \\
\hline $\begin{array}{c}\text { Aver } \\
\text { age }\end{array}$ & $50 \%$ & $64 \%$ & $76 \%$ & $81 \%$ \\
\hline
\end{tabular}

From the observation assessment of pre-cycle results obtained the average early childhood teachers' dancing ability of $d$ traditional dances is about $50 \%$, or 2 on a scale of 4 . This finding means that the teacher is still unable to dance traditional dances. In general the teacher is difficult to imitate to perform simple movement in dance, moving to the rhythm of music, coordination of body movements (eye-hand and foot), and balance of gestures at the time of movement. This is probably because that was the first time they heard the traditional music, the first time they saw the dance directly, and the first time they tried to dance.

The Cycle 1st was planning in a simple traditional dance material, which the researcher as its model. It was Opening with DVD Learning - Aku cinta Indonesia $k u$, the goals of this first treatment is to getting the students know about Indonesian, traditional dances from every province. Then at the second meeting it was Opening with a knowledge about the origin place of the dance, with DVD Learning - Selamat Datang di Sumatra Barat, get to know West Sumatra closer. And also introduction Sports for endurance and agility. In treatment 3 the class got an introduction of exercise about flexibility and strength, wich main exercise was tutorial Step 1. The students look very excited with the activity. Also in treatment 4 which opening warming up with endurance and agility, and then treatment 5 which warming up with flexibility and strength. The main exercise gave step by step after the warming up.

From day to day with the treatment, the students interest 
look increased, and also with their ability in traditional dance. Know the different movements of traditional Indonesian dance After the implementation of the cycle conducted as many as 7 times the meeting then re-evaluated the assessment. The results of the assessment observations in cycle 1 increased to $64 \%$ or if on a scale of 4 is in the stage of Self-sufficient. It means that the teacher began to be able to move to the rhythm of music, the balance of gestures began to well. As well as the coordination of good body movements (eye-hand and foot). But the results of the observations in cycle 1 still not reached the expected ability, the planning for cycle 2 as seen in the cycle planning table.

In cycle 2 students are freed to choose traditional dances that they enjoy. They looked for the performance first, then they choosed one of the dance which they like. After chosed one of the dance, they analyze every step of DVD tutorial dance movements. Then they tried to do step by step by followed the scheme. From the writer's observation, the teacher is very enthusiastic and happy when they got warming up with two kinds of exercises, for endurance and egality with aerobic exercise, or for strength and flexibility using yoga. So in the process of core dance practice they can move more easily. After the cycle 2 again performed the observation ability of traditional dance dance. From the results of the cycle 2 found that the ability to attract students increased to $76 \%$, or at good stage. And for the next they do staging at the end of the semester. From the results of the observation assessment, the students experienced a very significant improvement. Where in addition they are able to move to the rhythm of the music well, body development and coordination of movement to be good. They can dance thoroughly from start to finish with gestures that are no longer rigid. Some of them have been able to express themselves during dancing. That means they can enjoy the motion and music in the dance.

\section{CONCLUSION}

Exercise method with sport practice approach and tutorial DVD was able to improve early childhood teachers'dance ability of traditional dance whom they are as the students of Early Childhood Education Program, FIP-UMJ, Jakarta. By doing the exercises as a warming-up they make their movement better, allowing them to enjoy movement and music, which ultimately allows them to express themselves while dancing. Tutorial DVD has made them faster in learning traditional dances independently.

\section{Acknowledgement}

Thanks to Early Childhood Teacher Education Program, FIP UMJ who has facilitated this research.

\section{References}

[1] Thanks to Early Childhood Teacher Education Program, FIP UMJ who has facilitated this research.

[2] Robby Hidajat, Wawasan Seni Tari, Pengetahuan Praktis Bagi Guru Seni tari. Malang: Banjar seni Gantar Gumelar, 2005

[3] Linda Campbell, at.al, Metode Praktis Pembelajaran-Berbasis Multiple Intilligences. Jakarta: Intuisi Press, 2005
[4] Double, Margaret N.H, Dance - A Creative Art Experiences, terjemahan Kumorohadi. Surabaya: STK Wilwatika, 1985

[5] Robby Hidajat, Menerobos Pembelajaran Tari Pendidikan. Malang: Banjar seni Gantar Gumelar, 2005

[6] Sukadiyanto, Dangsina Muluk, Pengantar Teori dan Metodologi Melatih Fisik. Bandung: Lubuk Agung, 2011

[7] Shumway and Woollacott. Motor Control: Theory and Practical Applications. Philadelphia: Lippincott Williams \& Wilkins, 2001

[8] Schimdt, Richard. A., Motor Learning and Performance. Iowa: Human Kinetics Books, 1991

[9] Coker, Cheryl A, Motor Learning and Control for Practisioner. New York: McGraw Hill, 2004.

[10] Hujair AH Sanaky, Media Pembelajaran Interaktif-Inovatif, (Jakarta: Kaukaba Dipantara, 2013)

[11] Bompa, Tudor O, Theory and Methodology of Training The key to Athletic Performance. Iowa: Kendal/Hunt Publishing Company, 1994.

[12] Harsono, Coaching dan aspek-aspek Psikologis dalam Coaching. Jakarta, PIO KONI Pusat, CV Tambak Kusuma, 1988. 